\title{
GNRHR Positive
}

National Cancer Institute

\section{Source}

National Cancer Institute. GNRHR Positive. NCI Thesaurus. Code C150654.

An indication that expression of GNRHR has been detected in a sample. 